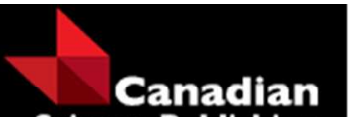
Science Publishing

Canadian Journal of Forest Research Revue canadienne de recherche forestière

\title{
Nutrient concentrations of roots vary with diameter, depth, and site in New Hampshire northern hardwoods
}

\begin{tabular}{|r|l|}
\hline Journal: & Canadian Journal of Forest Research \\
\hline Manuscript ID & cjfr-2017-0223.R1 \\
\hline Manuscript Type: & Article \\
\hline Date Submitted by the Author: & 31 -Aug-2017 \\
\hline Complete List of Authors: & $\begin{array}{l}\text { Yanai, Ruth; State University of New York } \\
\text { Walsh, Griffin; Yale University } \\
\text { Yang, Yang; SUNY-ESF, Forest and Natural Resources Management } \\
\text { Blodgett, Corrie; State University of New York } \\
\text { Bae, Kikang; Korea Forest Service } \\
\text { Park, Byung Bae; Chungnam National University }\end{array}$ \\
\hline Keyword: & nitrogen, phosphorus, calcium, magnesium, carbon \\
\hline $\begin{array}{r}\text { Is the invited manuscript for } \\
\text { consideration in a Special } \\
\text { Issue? : }\end{array}$ & N/A \\
\hline \hline
\end{tabular}


1

3 Ruth D. Yanai, Griffin E. Walsh, Yang Yang, Corrie A. Blodgett, Kikang Bae, and

4 Byung Bae Park

5

6 R.D. Yanai, G.E. Walsh, Y. Yang, C.A. Blodgett, K. Bae, and B.B Park. SUNY College

7 of Environmental Science and Forestry, 210 Marshall Hall, 1 Forestry Drive,

9

\section{Nutrient concentrations of roots vary with diameter, depth, and site in New} Hampshire northern hardwoods

Syracuse, NY 13210, USA. Tel: +1 315 470-6955, e-mail: rdyanai@syr.edu, fax: +1

$315-470-6954$

G.E. Walsh. Present address: Yale University, New Haven, CT. e-mail:

$$
\text { griffin.walsh@yale.edu }
$$

K. Bae. Present address: International Cooperation Division, Korea Forest Service, Government Complex-Daejeon, Bldg 1, 189 Cheongsa-ro, Seo-gu Daejeon 302-701, Republic of Korea

B.B. Park. Department of Forest Environment and Resources, Chungnam National University, College of Agriculture and Life Sciences, 99 Daehak-ro, Yuseong-gu, Daejeon 305-764, Republic of Korea. Tel: +82 42 821-5747, e-mail:
bbpark@cnu.ac.kr, fax: +82 42 825-7850 
19 Abstract

20 Roots are important to ecosystem nutrient pools and fluxes, but they are difficult to

21 sample for tissue analysis, especially at depth. We analyzed patterns of nutrient

22 concentrations in live roots up to $20 \mathrm{~mm}$ in diameter collected from quantitative soil pits

23 in six northern hardwood sites at the Bartlett Experimental Forest, New Hampshire,

24 USA. Root concentrations of nitrogen, phosphorus, calcium, and magnesium were

25 higher in the forest floor than in the mineral soil, by $23-61 \%$ in fine roots $(0-1 \mathrm{~mm}$ and

$26 \quad 1-2 \mathrm{~mm}$ in diameter). Using only samples collected from the O-horizon to characterize

27 roots throughout the profile resulted in an average error across all elements of $16 \%$ in

28 estimates of root nutrient contents. Within the mineral soil, there was little difference in

29 root nutrient concentrations with depth. There were significant patterns with root

30 diameter: $\mathrm{N}$ and $\mathrm{Mg}$ concentrations were highest in the finest roots, while $\mathrm{Ca}$

31 concentrations peaked in the $2-5 \mathrm{~mm}$ diameter class. One site (C8) differed from the

32 others in having lower $\mathrm{N}$ but higher $\mathrm{P}, \mathrm{Ca}, \mathrm{Mg}$, and $\mathrm{K}$ concentrations in roots. In

33 summary, analyzing roots by site and diameter class is more important to accurate

34 nutrient accounting than is analyzing roots from depth in the mineral soil, but roots in

35 the forest floor and the mineral soil differ dramatically for some elements.

\section{Keywords:}

37 Carbon, nitrogen, phosphorus, calcium, magnesium, potassium 


\section{Introduction}

Roots are very difficult to sample for tissue analysis compared to aboveground vegetation (Fahey et al. 2017), but they make up an important portion of ecosystem nutrient contents and nutrient turnover (Jackson et al 1997). It is especially difficult to sample roots at depth; roots obtained by coring methods are restricted to the top $30 \mathrm{~cm}$ or even less, in stony forest soils (Park et al. 2007). For this reason, it is important to know whether there are systematic changes in root tissue concentrations with depth in the soil. Such differences with soil depth have been described for nitrogen concentrations in fine roots of sugar maple in Michigan (Pregitzer et al. 1998), in hardwoods in Japan (Makita et al. 2011) and northeastern China (Wang et al. 2015), and in conifer forests in British Columbia (Kimmins and Hawkes 1978) and Japan (Ugawa et al. 2010). In deeply weathered tropical soils, roots have been excavated from depths of several meters and characterized for biomass but not nutrient concentrations (Hertel et al. 2009, Davidson et al. 2011). A study in the Ecuadorian Andes found no difference in root concentrations of nitrogen, phosphorus, sulfur, calcium, magnesium or potassium between organic and mineral soils, but did not test for differences with depth in the mineral soil (Soethe et al. 2007). If there were a significant pattern of concentration with depth, then using roots collected near the soil surface to describe all the roots in the ecosystem would result in a bias in estimates of their nutrient contents. Root diameter is known to be important to nutrient concentrations, with finer roots generally having higher concentrations (Gordon and Jackson 2000). Again, soil cores are appropriate for the collection of fine roots $(<2 \mathrm{~mm})$, but collecting larger roots requires more laborious collection methods. Two studies in tropical forests found fine roots to be higher than coarse roots in concentrations of $\mathrm{N}, \mathrm{P}$ and $\mathrm{Mg}$, but Ca was 
62 higher in coarser size classes, and K patterns differed by study (Edwards and Grubb

63 1982, Soethe et al. 2007). In a study of 49 species across seven sites from Siberia to

64 tropical China, $\mathrm{N}$ and $\mathrm{P}$ concentrations decreased with increasing root order, which

65 corresponds to increasing root diameter ( $\mathrm{Li}$ et al. 2010). In roots collected from soil pits

66 at the Hubbard Brook Experimental Forest in New Hampshire, N and P concentrations

67 decreased as root diameter increased (from $<0.6 \mathrm{~mm}$ to $>10 \mathrm{~mm}$ ), but Ca increased with

68 increasing root diameter and $\mathrm{K}$ and $\mathrm{Mg}$ were highest in $0.6-1 \mathrm{~mm}$ roots (Fahey et al.

69 1988). For $\mathrm{Ca}$, the bark of these roots had much higher concentration than the wood, so

70 root concentrations by species depended on the proportion of bark to wood (Fahey et al.

71 1988).

72 The objective of this study was to describe elemental concentrations in live roots

73 in six northern hardwood stands in the Bartlett Experimental Forest in New Hampshire.

74 The excavation of soil pits in these sites provided access to roots of greater diameter and

75 from greater soil depths than is normally possible to collect with traditional coring

76 methods. We tested the importance of root diameter and soil depth in explaining

77 variation in root concentrations of $\mathrm{N}, \mathrm{P}, \mathrm{Ca}, \mathrm{Mg}$, and $\mathrm{K}$. We expected to find differences

78 in concentrations as a function of root diameter, but because of the difficulty of

79 sampling deep roots, we hoped to find only minor differences in root chemistry with

80 soil depth. We calculated the nutrient contents of roots to evaluate the importance of

81 information about concentration as a function of soil depth.

\section{Methods}

$83 \quad$ Site Description

84 We studied roots in six sites of three stand ages in the Bartlett Experimental

85 Forest $\left(44^{\circ} 02-04^{\prime} \mathrm{N}, 71^{\circ} 16-19^{\prime} \mathrm{W}\right)$, as part of a larger study on nutrient cycling during 
stand development (Yanai et al. 2006, Park et al. 2007). The climate is humid continental with average annual precipitation of $1270 \mathrm{~mm}$. The soils are Spodosols developed in granitic glacial drift. The $\mathrm{O}$ horizon (forest floor) averages $5.1 \mathrm{~cm}$ in depth in the sites we studied (Vadeboncoeur et al. 2012). In the U.S. Soil Taxonomy, the horizons of the forest floor are designated Oi, Oe, Oa (Soil Survey Staff 1975), corresponding to L, F, and H in the Canadian System of Soil Classification (Soil Classification Group 1998).

Forest composition around the soil pits differed by site, in part reflecting successional dynamics following forest harvest (Table 1). The young stands (age 14 and 16) were dominated by pin cherry (Prunus pennsylvanica L.f.) and American beech (Fagus grandifolia Ehrh.), followed by white birch (Betula papyrifera Marsh.) and yellow birch (B. allegheniensis Britton). The young-transitional stands (age 26 and 29) had a smaller proportion of pin cherry; red maple (Acer rubrum L.) was important in one of the stands. The older stands (age 114 and 121) were dominated by sugar maple (Acer saccharum Marsh.) and American beech.

\section{Root Collection}

In each site, roots were collected in summer 2004 from three $0.5 \mathrm{~m}^{2}$ quantitative soils pits, each located in one of three replicate 0.25 -ha plots in each site, resulting in pit separations of 40 to $130 \mathrm{~m}$ within sites. For the Oie, which can't be sieved for roots, three $100-\mathrm{cm}^{2}$ samples were cut with a template and returned to the lab for root picking. The Oa was removed and sieved through a 6-mm screen. The mineral soil was excavated by depth increment $(0-10,10-30$, and $30-50 \mathrm{~cm})$ and sieved through a $12-\mathrm{mm}$ screen. The roots that remained on the screen were returned to the lab and refrigerated until they could be processed. Material that passed through the screen was subsampled 
110 and roots picked from the sieved soil are included in our estimates of biomass. More

111 detail on root collection and processing was reported by Park et al. (2007).

\section{Root Analysis}

Roots were sorted, washed, dried, and weighed in 2004 as part of the earlier study (Park et al. 2007). Live roots, identified by color and turgor, were sorted into size classes: $0-1,1-2,2-5,5-10,10-20$, and $>20 \mathrm{~mm}$ in diameter. For the analysis of root chemistry, we used the roots collected on the screens in the field or picked from the Oie blocks. For the larger roots $(>2 \mathrm{~mm})$, these were all the roots found in the pits; for the 0 1 and 1-2 mm roots, these were 34 and $85 \%$, respectively, of the mass of roots reported from the pits. Large samples were subsampled before being sorted into vitality and size classes, and multiple subsamples were washed, dried, and weighed. In these cases, the roots were composited for analysis in proportion to the biomass represented by each sample.

Because it would have been prohibitively expensive to analyze every root sample, we selected classes of roots to analyze across the combinations of soil depth, root diameter, and site. For a comprehensive comparison of the five diameter classes, we chose the $0-10 \mathrm{~cm}$ soil depth, which has the greatest representation of size classes. This soil depth also tended to have the greatest root mass, though in the older stands, there was more biomass in the 10-30 $\mathrm{cm}$ depth (Park et al. 2007). To compare concentrations of roots from multiple soil depths, we focused on the $0-1 \mathrm{~mm}$ diameter class, which comprises the majority of root biomass $<10 \mathrm{~mm}$ in diameter (Park et al. 2007). We also analyzed 2-5 $\mathrm{mm}$ diameter roots from all depths except the Oie, where such coarse roots are rare. In some depth increments and size classes, to reduce the analytical load, we composited roots across pits within sites for one of the sites in each 
age class $(\mathrm{C} 2, \mathrm{C} 4$, and $\mathrm{C} 9)$. In these three sites, we also analyzed composite samples of additional combinations of root diameter and soil depth classes. For $\mathrm{C} 1, \mathrm{C} 6$, and $\mathrm{C} 8$, we analyzed samples separately for each of the three pits in each site. In total, 174 samples were analyzed.

Roots were ground in a Willey mill $(2 \mathrm{~mm}$ screen $)$ and oven-dried at $60{ }^{\circ} \mathrm{C}$ before weighing out $0.25-1.0 \mathrm{~g}$ for analysis. The samples were ashed at $470{ }^{\circ} \mathrm{C}$ and dissolved in $10 \mathrm{~mL}$ of $6 \mathrm{~N}$ nitric acid. The solutions were filtered, diluted to $50 \mathrm{~mL}$ with distilled, deionized water, and analyzed for $\mathrm{Ca}, \mathrm{Mg}, \mathrm{K}$, and $\mathrm{P}$ using inductively coupled plasma optical emission spectrometry (ICP-OES) (PE-3300DV, Perkin Elmer, Shelton, CT). For N analysis, samples were pulverized (Zenith/DMG Variable Speed Dental Amalgamator, Englewood, NJ) and analyzed by dry combustion (Vario EL, Elementar Americas, Mount Laurel, NJ).

We used the $\mathrm{C}$ content of roots to evaluate contamination of root samples by adhering soil. Roots from the $\mathrm{O}$ horizon have little mineral material associated with them, compared to roots from greater depths. There was a slight but significant difference in $\mathrm{C}$ concentration with depth $(p=0.02$ for the main effect of depth in ANOVA): the average $\mathrm{C}$ concentration of roots was $49 \%$ in the Oa and $47 \%$ in the mineral soil. There were no differences with depth within the mineral soil. We did not correct for soil contamination of roots, as the difference amounted to only $2 \%$ of the mass of the roots.

\section{Statistical Analysis}

Root concentrations were compared separately for each element using analysis of variance with repeated measures of the soil pits using proc mixed in SAS. We assessed the effect of site (6 levels), root diameter (5 levels) and soil depth (5 levels), 
with the 3 pits nested within site. We included all the two-way interaction terms in the model. We repeated the analysis after excluding one site (C8) from the above analyses to assess the degree to which it controlled the results by site.

Least-square means were used to compare sites, root diameter classes within depths, and soil depths for each root diameter class. For the main effect of root diameter on $\mathrm{N}, \mathrm{P}, \mathrm{K}, \mathrm{Ca}$ and $\mathrm{Mg}$ concentrations, coarse (5-10 and 10-20 mm) and fine roots (0-1 $\mathrm{mm}$ and 1-2 $\mathrm{mm}$ ) were compared with a contrast statement. To describe the effect of soil depth on coarse and fine root concentrations, we compared weighted concentrations from the $\mathrm{O}$ horizon with those from the mineral soil. We report the difference as a percentage of the mineral soil concentration.

To test the effect of stand age (3 levels), we included root diameter (5 levels), soil depth (4 level) and their interactions, with sites nested within age, in a repeatedmeasures ANOVA. The Oie was omitted from this analysis because of a lack of replication in the youngest age class. We repeated the analysis of stand age after excluding one site (C8) from the analysis to assess the degree to which it controlled the results by stand age.

\section{Calculation of Root Nutrient Content}

To calculate root nutrient contents, we used the mass of roots previously reported (Park et al. 2007) and the nutrient concentrations we measured from a subset of those samples. For the 174 samples that were analyzed, we used the observed concentrations. Because we did not analyze concentrations for every combination of root size and depth classes, we estimated the other nutrient concentrations using the coefficients from the repeated-measures ANOVA described above, using proc plm for postfitting in SAS. In addition, there were two classes of roots that were too rare to be 
182 included in the ANOVA, but which needed to be estimated for nutrient contents. First, 183 to estimate concentrations in roots $>1 \mathrm{~mm}$ in diameter in the Oie, we assigned 184 concentrations from the same diameter of roots in the Oa horizon. Second, roots $>10$

$185 \mathrm{~mm}$ in diameter were analyzed for concentration only at $0-10 \mathrm{~cm}$ depth, but 186 occasionally this size class occurred at other depths. For C, N, and P, we used root 187 concentrations for this size class from the $0-10 \mathrm{~cm}$ depth roots, because these elements 188 showed a strong relationship with diameter. For $\mathrm{Ca}, \mathrm{Mg}$, and $\mathrm{K}$, we used concentrations 189 from the 5-10 mm diameter class from the same depth, because these elements showed 190 a stronger trend with depth (Fig. 2). Root nutrient content was calculated as the product of root biomass and root chemical concentration. We included roots up to $100 \mathrm{~mm}$ in each site as replicates.

\section{Results}

203 Concentrations vary with root diameter 
206 higher in concentration, by $80 \%$ for $\mathrm{N}, 49 \%$ for $\mathrm{Mg}$, and $13 \%$ for $\mathrm{K}$, comparing $<2 \mathrm{~mm}$ 207 roots to roots 5-20 $\mathrm{mm}$ in diameter (Fig. 1). For Ca, in contrast, fine roots had 208 concentrations $10 \%$ lower than the coarse roots, and the peak Ca concentrations 209 occurred in the 2-5 mm diameter class. For P, the effect of root diameter was much 210 stronger if site C8 was excluded from the analysis. Compared to coarse roots, fine roots 211 were $62 \%$ higher in concentration with all sites included $\mathrm{P}(p=0.10)$, but $91 \%$ higher 212 excluding C8 $(p=0.001)$, which was high in concentrations of $\mathrm{P}$ and other elements, as 213 described below.

214 The effect of diameter on concentration depended on depth for three elements.

215 For $\mathrm{N}(p<0.001)$, fine roots were higher $\mathrm{N}$ concentrations than coarse roots at all 216 depths, but the differences between fine and coarse roots were greater in the Oa horizon $217(120 \%)$ than in the $30-50 \mathrm{~cm}$ mineral soil depth $(21 \%)(p<0.01)$. For K, there was a 218 reversal of the difference with depth $(p=0.03)$ : fine roots were $93 \%$ higher in $\mathrm{K}$ 219 concentration than coarse roots at $30-50 \mathrm{~cm}(p<0.01)$, but in the Oa horizon, the fine roots had $8 \%$ lower concentration $(p=0.23)$. For $\mathrm{Ca}$, fine roots were $15-23 \%$ lower in Ca concentration than coarse roots at $0-10,10-30$ and 30-50 $\mathrm{cm}(p<0.01)$, but in the Oa horizon, the fine roots had $16 \%$ higher concentration $(p=0.002)$.

\section{Concentrations vary with soil depth}

There were important differences in the nutrient concentrations of roots as a function of soil depth (Fig. 1, Table 2), with significant declines in concentration with depth for $\mathrm{N}(p<0.001), \mathrm{P}(p<0.001), \mathrm{Ca}(p<0.001)$, and $\mathrm{Mg}(p \leq 0.006)$ but not $\mathrm{K}(p$

$227 \geq 0.67)$. For fine roots $(0-1 \mathrm{~mm}$ and $1-2 \mathrm{~mm})$, concentrations in the $\mathrm{O}$ horizons were $40 \%$ higher for $\mathrm{N}(p=0.01), 61 \%$ higher for $\mathrm{P}(p<0.001), 56 \%$ higher for $\mathrm{Ca}(p=$ $0.002)$ and $23 \%$ higher for $\operatorname{Mg}(p=0.02)$ than those in the mineral soil (Fig. 1). For 
230

231

232

233

234

235

236

237

238

239

240

241

242

243

244

245

246

247

248

249

250

251

252

coarse roots (5-10 and 10-20 mm), the differences with soil depth were not significant for any element.

\section{Concentration patterns with stand age and site}

The roots we studied were collected in replicate stands of three ages. There were no significant differences in root nutrient concentrations with stand age $(p \geq 0.17)$. There was one site, $\mathrm{C} 8$, that differed significantly from the others for all the nutrients. For $\mathrm{N}(p<0.01)$, this site was significantly lower than the others. For $\mathrm{P}(p=$ $0.01), \mathrm{Ca}(p=0.008), \mathrm{Mg}(p<0.001)$, and $\mathrm{K}(p=0.02)$, roots in $\mathrm{C} 8$ had significantly higher concentrations than roots in other sites. When C8 was removed from the analysis, site was not significant for any element $(p>0.06)$.

Some of the other effects we observed depended on this site. The significance of diameter effects on $\mathrm{K}$ and $\mathrm{P}$ differed with and without C8 (Table 2). Including all sites, diameter was significant for $\mathrm{K}(p=0.01)$ but not $\mathrm{P}(p=0.10)$. Excluding site $\mathrm{C} 8$, diameter was significant for $\mathrm{P}(p=0.001)$ but not $\mathrm{K}(p=0.11)$. The significant interactions of depth and diameter on $\mathrm{Ca}$ and $\mathrm{K}$ concentrations, described above, were not very significant without $\mathrm{C} 8$ ( $p=0.09$ and 0.08 , respectively).

\section{Root nutrient content}

Across the six sites, the elemental contents of roots $<20 \mathrm{~mm}$ in diameter in the whole soil profile averaged $7.4 \mathrm{~g} \mathrm{~m}^{2}$ for $\mathrm{Ca}, 4.3 \mathrm{~g} \mathrm{~m}^{-2}$ for $\mathrm{K}, 1.1 \mathrm{~g} \mathrm{~m}^{-2}$ for $\mathrm{Mg}, 13.9 \mathrm{~g} \mathrm{~m}^{-}$ ${ }^{2}$ for $\mathrm{N}, 0.76 \mathrm{~g} \mathrm{~m}^{-2}$ for $\mathrm{P}$, and $851 \mathrm{~g} \mathrm{~m}^{-2}$ for $\mathrm{C}$ (Table 3). The coefficient of variation of elemental contents across sites was the largest for P and $\mathrm{N}$ (both 36\%) and smallest for $\mathrm{C}(23 \%)$. With the exception of $\mathrm{Ca}$, roots $<1 \mathrm{~mm}$ accounted for a greater fraction of total root nutrient contents than their mass or $\mathrm{C}$ contents, because they had higher 
nutrient concentrations than coarser roots (Table 3, Fig. 2). For example, 55\% of $\mathrm{N}$ was in the $<1 \mathrm{~mm}$ roots, on average, although this size class accounted for $44 \%$ of the total root mass $<20 \mathrm{~mm}$ in diameter. For both $\mathrm{Mg}$ and $\mathrm{P}$, the fraction found in the $<1 \mathrm{~mm}$ roots was $50 \%$. However, for $\mathrm{Ca}$, which occurs at higher concentration in coarser roots, the portion of root nutrient contents in the $<1 \mathrm{~mm}$ size class averaged only $37 \%$.

We tested the importance of sampling roots at depth by calculating the nutrient contents of roots up to $20 \mathrm{~mm}$ in diameter in our six sites based on roots from various depth combinations (Fig. 2). The biggest discrepancy between root nutrient content prediction methods occurred between using concentrations of roots only in the Oa and the best estimates using all our data. For $\mathrm{N}$, the average error across the three soil pits ranged from $11-28 \%$, depending on the site. For $\mathrm{P}$, this range was $1-58 \%$ and for $\mathrm{Ca},-3-$ $68 \%$. For $\mathrm{Mg}$ and $\mathrm{K}$, using roots from the Oa to represent the whole profile agreed within $-12-29 \%(\mathrm{Mg})$ or $-16-29 \%(\mathrm{~K})$, which is consistent with a lack of significant variation in concentrations with depth (Table 2). We also compared the root nutrient contents of the mineral soil based on sampling only from the $0-10 \mathrm{~cm}$ depth. The errors introduced by this sampling scheme were smaller: $-7-2 \%$ for $\mathrm{N},-45-2 \%$ for $\mathrm{P},-13-30 \%$ for $\mathrm{Ca},-23-2 \%$ for $\mathrm{Mg}$, and $-13-12 \%$ for $\mathrm{K}$. Because fewer roots occur at depth than in the surface horizons, the difference in the nutrient content of roots calculated using data only from superficial roots (Fig. 2) was smaller than the difference in concentration

\section{(Fig. 1).}

\section{Discussion}

\section{Patterns with root diameter}

In aboveground tissues, nutrient concentrations are generally lowest in boles and higher in branches and twigs, because wood is low in nutrients. Nutrient concentrations 
277 of roots of different diameters have been compared at other northern hardwood sites, 278 with most elements usually higher in concentration in the finest roots. At Huntington 279 Forest, in the Adirondacks, sugar maple and beech had higher concentrations of N, P, 280 and $\mathrm{Mg}$ in finer (0-1 $\mathrm{mm})$ than coarser (2-5 mm) roots (Park and Yanai 2009), as was 281 the case in this study. Similarly, studies of $\mathrm{N}$ as a function of root order have found the 282 highest concentrations in the most distal roots, with diameters ranging from $<0.2$ to $>3$

and larch in northeastern China (Jia et al. 2013). At Hubbard Brook in the White

Mountains, however, fine roots $(<0.6 \mathrm{~mm}$, all species combined) had lower $\mathrm{Mg}$

concentrations than small woody roots $(0.6-10 \mathrm{~mm})$ in sugar maple, beech, yellow birch, and red spruce, although other nutrient concentrations were higher in the finer roots (Fahey et al. 1988).

Calcium peaked at intermediate diameters in our data set (Fig. 1), which was also the case in a study of black spruce, Jack pine, and sugar maple in Quebec, in which Ca concentrations peaked in roots $0.2-0.5 \mathrm{~mm}$ and $0.5-1 \mathrm{~mm}$, then decreased with diameter to $>10 \mathrm{~mm}$ (Ouimet et al. 2008). In contrast, roots of sugar maple, yellow birch, American beech, and red spruce at Hubbard Brook, Ca concentrations increased up to roots $>10 \mathrm{~mm}$, Fahey et al. 1988). Some studies that have found Ca to increase with root diameter have not sampled roots $>5 \mathrm{~mm}$ (Wargo et al. 2003, Park 2006, Park and Yanai 2009). Clearly, where changes with diameter are non-linear, observations of trends with root diameter will depend on which part of the diameter range is observed. For K, we did not find a consistent difference between fine and coarse roots, but rather an interaction between depth and diameter (Table 2, Fig. 1). The Hubbard Brook data set shows coarser roots $(>10 \mathrm{~mm})$ to be lower in $\mathrm{K}$ concentration than finer roots 
301 (Fahey et al. 1988), which we observed at 30-50 $\mathrm{cm}$ depth. In a cross-site comparison

302 that included Sleepers River and Cone Pond as well as Hubbard Brook (Park 2006),

303 roots from softwood and hardwood stands at all three sites had higher K concentrations

304 in the 1-2 mm diameter class than in two finer size classes, but coarser roots were not

305 studied (Park 2006). The generalization that woody roots are lower in nutrients than

306 finer roots is far from universal.

\section{Patterns with depth}

Declines in root concentrations of $\mathrm{N}$ with soil depth have been well documented (Kimmins and Hawkes 1978, Pregitzer et al. 1998, Ugawa et al 2010). In our sites, we floor having concentrations 40 to $60 \%$ higher than in the mineral soil. These elements are likely to be most limiting to forest growth and most tightly conserved, with mineralization of organic forms in the forest floor playing an important role in nutrient conservation. Roots also differ in function with depth, and a greater concentration of proteins, which are high in $\mathrm{N}$, is presumably of more value near the soil surface, where more nutrient uptake occurs, than at depth, where roots may be serving more for water than nutrient uptake.

The base cations $\mathrm{Ca}, \mathrm{Mg}$, and $\mathrm{K}$ had differing behaviors in our study, although these elements are cycled through cation exchange, and weathering sources originate in the mineral soil. Specifically, Ca declined most strongly, $\mathrm{Mg}$ was intermediate, and $\mathrm{K}$ was not sensitive to soil depth. Scots pine in England had declining concentrations of $\mathrm{Ca}$ and $\mathrm{Mg}$ from 0 to $60 \mathrm{~cm}$ depth in the mineral soil (Vanguelova et al. 2005). Norway spruce in Germany had 27\% higher concentrations of $\mathrm{Ca}$ in roots in organic than 
324 mineral soil, while N, P, and K showed less significant effects of soil depth across the 325 four sites sampled (Borken et al. 2007).

326 The high cost of sampling roots deep in the soil profile means that it may not be 327 practical to include this source of variation when constructing nutrient budgets. The 328 differences in nutrient concentrations with depth within the mineral soil were generally would be wise to sample roots from at least the upper mineral soil in ecosystems such as these.

\section{Patterns with site}

One of the sites we studied (C8) differed significantly from the others in the concentrations of nutrients in roots. Differences in root chemistry across sites forested with northern hardwoods have been reported by other studies. For example, in Quebec, $\mathrm{Ca}, \mathrm{Mg}$, and $\mathrm{K}$ concentrations in roots were higher in sites with higher soil base saturation (Ouimet et al. 2008). Similarly, roots had high $\mathrm{Ca}, \mathrm{Mg}$, and $\mathrm{K}$ in at Sleepers River, VT, a site with high base saturation, compared to Hubbard Brook and Cone Pond, while P concentrations were highest at Hubbard Brook (Park 2006). At Huntington Forest, NY, catchments with contrasting soils differed in root chemistry by a factor of 5 for $\mathrm{Ca}$ and 2 for $\mathrm{Mg}$, whereas $\mathrm{K}$ concentrations showed no trends with soil nutrient availability (Park and Yanai 2009). We have data on exchangeable bases in our soil pits (Schaller et al. 2010), but they do not explain the high concentrations of $\mathrm{Ca}, \mathrm{Mg}$ and $\mathrm{K}$ in site $\mathrm{C} 8$. The high $\mathrm{P}$ concentrations in roots in $\mathrm{C} 8$ are consistent with high $\mathrm{P}$ concentrations in soil and foliage at that site (See et al. 2015), though site C9 had even higher soil P (Vadeboncoeur et al. 2014). Low $\mathrm{N}$ in roots at this site is consistent with 
347 high $\mathrm{P}$ availability, as this site is likely $\mathrm{N}$ limited, while the rest are more P limited 348 (Gonzales 2017).

349 Species differences in root chemistry were not addressed in this study but could 350 contribute to variation across sites. Sugar maple, which was important only in the two 351 mature sites (Table 1), was reported to be high in P at Hubbard Brook (Fahey et al. 352 1988). However, at Huntington Forest, where beech and sugar maple were studied in 353 contrasting sites, species differences were small compared to site differences (Park and 354 Yanai 2009). Site C8 does not differ dramatically in species composition from the other 355 sites in the study (Table 1).

356 Tree health might also explain some variation associated with site; $\mathrm{P}$ and $\mathrm{Ca}$ in 357 fine roots were lower in declining sugar maples in Quebec than in healthy trees (Ouimet et al. 1995). Sugar maples in our sites were healthy, but beech, which comprised from 12 to $45 \%$ of basal area in our stands (Table 1) suffered from beech bark disease.

\section{Recommendations}

The results from this study confirm the importance of sampling roots by site, since concentrations of nutrients in roots varied by a factor of two, even in similar forests at nearby sites. Variation in root chemistry with depth was important, with roots in the forest floor having significantly different concentrations than roots at depth, which suggests that roots should be sampled in both organic and mineral horizons, in forests where the forest floor is important. In the sites we studied, differences with depth within the mineral soil were not as important, suggesting that sampling in the mineral soil could be focused on roots near the surface, which are easier to collect. In other ecosystem types, both the distribution of root biomass with depth and the possibility of 
370 concentration differences with depth need to be considered in evaluating root sampling 371 regimes.

\section{Acknowledgments}

373 The excavation of 6.44 metric tons of soil and roots was accomplished by Robin 374 Averbeck, Corrie Blodgett, Molly Deringer, Colin Fuss, Meredith Germain, Shefije 375 Miftari, Nicole Shapiro, Dan Tucker, and Brian Weeks under the direction of Matt 376 Vadeboncoeur and Steve Hamburg. Sorting roots, an equally arduous task, was 377 accomplished by Asuka Matsuzaki, Mutsumi Nishii, Gwen Kernan, Byung Kwon Park, 378 and Amber Knowlden. The roots were exhumed from the archives, selected, and 379 processed by Andrew Mishler, Bill O'Neill, Christina Allison, and Griffin Walsh. The 380 digested samples were analyzed by Sanae Kuwagaki, Dusty Wood, Sarah Worsham, 381 and Griffin Walsh. Nitrogen was run in the lab of Christy Goodale with help from 382 Alexis Heinz and Guin Fredriksen. Eddie Bevilacqua provided guidance on statistical analyses. This work was funded by grants from the National Science Foundation (DEB 0235650 and 0949550$)$.

\section{References}

Borken, W, Kossmann, G and Matzner, E. 2007. Biomass, morphology and nutrient contents of fine roots in four Norway spruce stands. Plant Soil. 292: 79-93.

Davidson, E., Lefebvre, P.A., Brando, P.M., Ray, D.M., Trumbore, S.E., Solorzano, L.A., Ferreira, J.N., Bustamante, M.M. da C., and Nepstad, D.C. 2011. Carbon inputs and water uptake in deep soils of an eastern Amazon forest. For. Sci. 57(1):51-58. 
392 Edwards, P.J., and Grubb, P.J. 1982. Studies of mineral cycling in a montane rainforest 393 in New Guinea: IV. soil characteristics and the division of mineral elements 394 between the vegetation and soil. J. Ecol. 70(2): 649-666.

395 Fahey, T.J., Hughes, J.W., Pu, M., and Arthur, M.A. 1988. Root decomposition and 396 nutrient flux following whole-tree harvest of northern hardwood forest. For. Sci. 34:744-768.

Fahey, T.J., Yanai R.D., Gonzales K.E., and Lombardi J.A. 2017. Sampling and processing roots from rocky forest soils. Ecosphere 8(6). DOI: 10.1002/ecs2.1863.

Gordon, W.S., and Jackson, R.B. 2000. Nutrient concentrations in fine roots. Ecology 81: $275-280$.

Gonzales, K.E. 2017. Effects of calcium, nitrogen, and phosphorus fertilization on foliar nutrient dynamics of three northern hardwood tree species. MS Thesis. SUNY College of Environmental Science and Forestry. Syracuse, NY. 116 p.

Hertel, D., Moser, G., Culmsee, H., Erasmi, S., Horna, V., Schuldt, B., and Leuschner, Ch. 2009. Below- and above-ground biomass and net primary production in a paleotropical natural forest (Sulawesi, Indonesia) as compared to neotropical forests. For. Ecol Manage. 258:1904-1912.

Jackson, R.B., Mooney, H.A., and Schlze, E.D. 1997. A global budget for fine root biomass, surface area, and nutrient contents. Proc. Natl. Acad. Sci. USA 94:7362-7366.

Jia, S., McLaughlin, N.B., Gu, J., Li, X. and Wang, Z., 2013. Relationships between root respiration rate and root morphology, chemistry and anatomy in Larix gmelinii and Fraxinus mandshurica. Tree physiology. 33: 579-589. 
416 Kimmins, J.P., and Hawkes, B.C. 1978. Distribution and chemistry of fine roots in a

417

418

419

420 white spruce - subalpine fir stand in British Columbia: implications for management. Can. J. For. Res. 8(3):265-279.

Li, A., Guo, D., Wang, Z., and Liu, H. 2010. Nitrogen and phosphorus allocation in leaves, twigs, and fine roots across 49 temperate, subtropical and tropical tree species: a hierarchical pattern. Functional Ecology. 24: 224-232. Doi: 10.1111/j.1365-2435.2009.01603.x.

Makita, N., Hirano Y., Mizoguchi, T., Kominami, Y., Dannoura, M., Ishii, H., Finér, L., and Kanazawa, Y. 2011. Very Fine Roots Respond to Soil Depth: Biomass Allocation, Morphology, and Physiology in a Broad-Leaved Temperate Forest. Ecological Research. 26(1): 95-104. DOI:10.1007/s11284-010-0764-5.

Ouimet, R., Camiré, C., and Furlan, V. 1995. Endomycorrhizal status of sugar maple in relation to tree decline and foliar, fine-roots, and soil chemistry in the Beauce region, Québec. Can. J. Bot. 73: 1168-1175.

Ouimet, R., Camiré, C., Brazeau, M., and Moore, J-D. 2008. Estimation of coarse root biomass and nutrient content for sugar maple, Jack pine, and black spruce using stem diameter at breast height. Can. J. For. Res. 38: 92-100.

Park, B.B., 2006. Fine root dynamics and tissue chemistry across a calcium gradient in temperate hardwood and softwood forest ecosystems. Ph. D. thesis, Department of Forest and Natural Resources Management, the State University of New York. College of Environmental Science and Forestry, Syracuse, NY, 2006.

Park, B.B., and Yanai, R.D. 2009. Nutrient concentrations in roots, leaves and wood of seedling and mature sugar maple and American beech at two contrasting sites. For. Ecol. Manage. 258(7):1153-1160. 
440 Park, B.B., Yanai, R.D., Vadeboncoeur, M.A., and Hamburg, S.P. 2007. Estimating root 441 biomass in rocky soils using pits, cores and allometric equations. Soil. Sci. Soc. $442 \quad$ Am. J. 71:206-213.

443 Pregitzer, K.S., Kubiske, M.E., Yu, C.K., and Hendrick, R.L. 1997. Relationships 444 among root branch order, carbon, and nitrogen in four temperate species. $445 \quad$ Oecologia 111:302-308.

446 Pregitzer, K.S., Laskowski, M.J., Barton, A.J., Lessard, V.C., and Zak, D.R. 1998.

$447 \quad$ Variation in sugar maple root respiration with root diameter and soil depth. Tree 
Ugawa, S., Miura, S., Iwamoto, K., Kaneko, S., and Fukuda, K. 2010. Vertical patterns of fine root biomass, morphology and nitrogen concentration in a subalpine firwave forest. Plant Soil 335:469-478.

Vadeboncoeur, M.A., Hamburg, S.P., Blum, J.D., Pennino, M.J., Yanai, R.D., and Johnson, C.E. 2012. The quantitative soil pit method for measuring belowground carbon and nitrogen stocks. Soil Sci. Soc. Am. J. 76:2241-2255. DOI: $10.2136 /$ sssaj2012.0111.

Vadeboncoeur, M.A., Hamburg S.P., Yanai R.D., and Blum J.D. 2014. Rates of sustainable forest harvest depend on rotation length and weathering of soil minerals. For. Ecol. Manag. 318: 194-205. DOI:10.1016/j.foreco.2014.01.012.

Vanguelova, E. I., Nortcliff, S., Moffat, A. J. and Kennedy, F. 2005. Morphology, biomass and nutrient status of fine roots of Scots pine (Pinus sylvestris) as influenced by seasonal fluctuations in soil moisture and soil solution chemistry. Plant and soil 270: 233-247.

Vanguelova E.I., Hirano Y., Eldhuset T.D., Sas-Paszt L., Bakker M.R., Püttsepp Ü., Brunner I., Lõhmus, K., and Godbold, D. 2007. Tree fine root $\mathrm{Ca} / \mathrm{Al}$ molar ratio - Indicator of Al and acidity stress. Plant Biosyst. 141(3):460-480.

Wang, Y., Dong, X., Wang, H., Wang, Z., and Gu, J. 2015. Root tip morphology, anatomy, chemistry and potential hydraulic conductivity vary with soil depth in three temperate hardwood species. Tree Physiology. 36: 99-108. DOI: 10.1093/treephys/tpv094

Wargo P.M., Vogt K., Vogt D., Holifield Q., Tilley J., Lawrence G., and David M.. 2003. Vitality and chemistry of roots of red spruce in forest floors of stands with 

a gradient of soil Al/Ca ratios in the northeastern United States. Can. J. For. Res. 33(4): 635-652. DOI: 10.1139/x02-195.

487 Yanai, R.D., Park, B.B., and Hamburg, S.P. 2006. The vertical and horizontal 488 distribution of roots in northern hardwood stands of varying age. Can. J. For.

489 Res. 36:450-459. 
490 Table 1. Basal area by species of trees near the soil pits from which roots were

491 collected, based on trees $>2 \mathrm{~cm}$ dbh within $3 \mathrm{~m}$ and trees $>10 \mathrm{~cm}$ dbh within $6 \mathrm{~m}$ of the

492 center of the pit; species are listed in decreasing order of importance.

\begin{tabular}{lcccccc}
\hline & \multicolumn{7}{c}{ Basal Area $\left(\mathrm{m}^{2}\right.$ ha $\left.^{-1}\right)$} \\
\multicolumn{1}{c}{ Site } & $\mathrm{C} 1$ & $\mathrm{C} 2$ & $\mathrm{C} 4$ & $\mathrm{C} 6$ & $\mathrm{C} 8$ & $\mathrm{C} 9$ \\
\multicolumn{1}{c}{ Stand Age (years) } & 14 & 16 & 26 & 29 & 121 & 114 \\
\hline American beech (Fagus grandifolia) & 2 & 6.5 & 3.5 & 8 & 7.3 & 12.7 \\
Sugar maple (Acer saccharum) & & 0.3 & & & 16.3 & 19.1 \\
Pin cherry (Prunus pennsylvanica) & 4.3 & 1.8 & 3.6 & 7.3 & & \\
White birch (Betula papyrifera) & 3 & 1.7 & 6 & 3.7 & 1.5 & 2.3 \\
Yellow birch (B. alleghaniensis) & 1.2 & 2 & 5.8 & 1.1 & & 4.6 \\
Red maple (A. rubrum) & 0.2 & 1.5 & 3.7 & 8.9 & 2.2 & \\
Aspen (Populus spp.) & & & 5.2 & & & \\
Eastern hemlock (Tsuga canadensis) & & 0.3 & & 2.1 & 0.3 & \\
Striped maple (A. pennsylvanicum) & 0.2 & 0.04 & 0.2 & 0.4 & & \\
Ash (Fraxinus spp.) & 0.1 & 0.3 & & & & \\
Other & 11.0 & 14.5 & 28.8 & 31.4 & 27.6 & 38.8 \\
\hline Total & & & & & &
\end{tabular}

* Stand ages pertain to 2004 , when the roots were collected. 
Table 2. Analysis of variance of root nutrient concentration as a function of site, soil depth, and root diameter

495

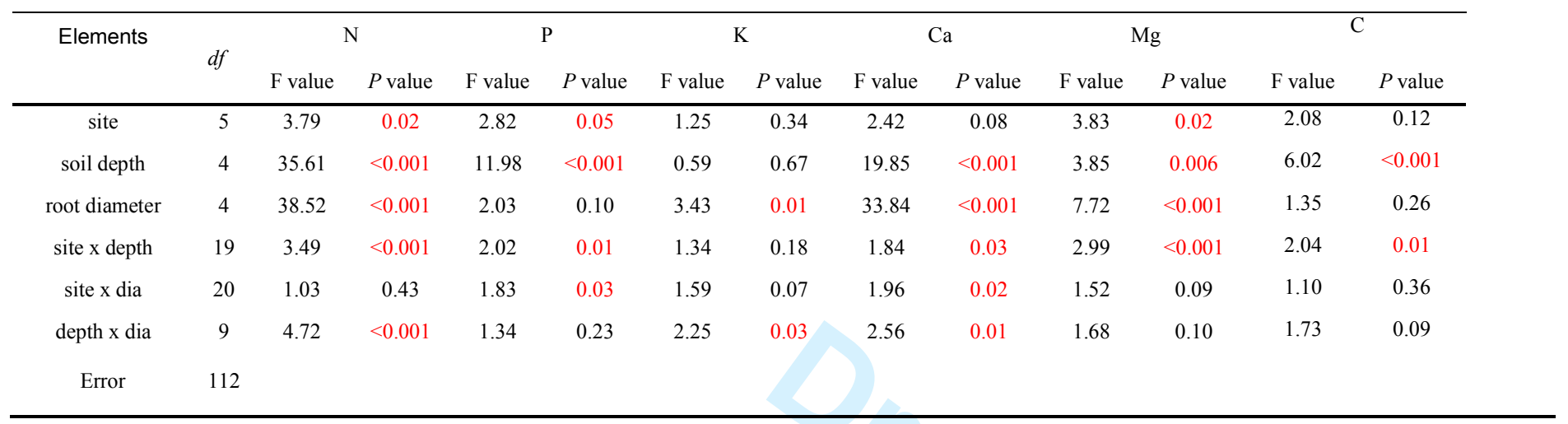

496

497

Based on 5 sites, excluding site C8.

\begin{tabular}{|c|c|c|c|c|c|c|c|c|c|c|c|c|c|}
\hline \multirow[t]{2}{*}{ Elements } & \multirow{2}{*}{$d f$} & \multicolumn{2}{|c|}{$\mathrm{N}$} & \multicolumn{2}{|c|}{$P$} & \multicolumn{2}{|c|}{$\mathrm{K}$} & \multicolumn{2}{|c|}{$\mathrm{Ca}$} & \multicolumn{2}{|c|}{$\mathrm{Mg}$} & \multicolumn{2}{|c|}{$\mathrm{C}$} \\
\hline & & F value & $P$ value & F value & $P$ value & F value & $P$ value & F value & $P$ value & F value & $P$ value & F value & $P$ value \\
\hline site & 4 & 1.54 & 0.25 & 1.45 & 0.27 & 0.87 & 0.51 & 0.79 & 0.55 & 2.66 & 0.08 & 1.62 & 0.23 \\
\hline root diameter & 4 & 30.47 & $<0.001$ & 4.93 & 0.001 & 1.99 & 0.11 & 25.15 & $<0.001$ & 8.47 & $<0.001$ & 2.10 & 0.09 \\
\hline site $\mathrm{x}$ depth & 15 & 2.56 & 0.004 & 1.93 & 0.03 & 1.07 & 0.40 & 1.54 & 0.11 & 2.85 & 0.001 & 2.29 & 0.01 \\
\hline depth $x$ dia & 9 & 3.29 & 0.002 & 1.56 & 0.14 & 1.78 & 0.08 & 1.77 & 0.09 & 1.64 & 0.12 & 1.21 & 0.30 \\
\hline Error & 89 & & & & & & & & & & & & \\
\hline
\end{tabular}

498 
Table 3a. Root nutrient contents $\left(\mathrm{g} \mathrm{m}^{-2}\right)$ by root diameter (Mean $\pm \mathrm{SE}$ ).

\begin{tabular}{|c|c|c|c|c|c|c|c|c|c|c|c|c|}
\hline \multirow{2}{*}{$\begin{array}{c}\text { Elements } \\
\text { Site }\end{array}$} & \multicolumn{6}{|c|}{$\mathrm{C}$} & \multicolumn{6}{|c|}{$\mathrm{N}$} \\
\hline & $\mathrm{C} 1$ & $\mathrm{C} 2$ & $\mathrm{C} 4$ & C6 & $\mathrm{C} 8$ & C9 & $\mathrm{C} 1$ & $\mathrm{C} 2$ & $\mathrm{C} 4$ & C6 & $\mathrm{C} 8$ & C9 \\
\hline $0-1$ & $427 \pm 155$ & $327 \pm 29$ & $457 \pm 31$ & $363 \pm 35$ & $408 \pm 64$ & $511 \pm 16$ & $6.3 \pm 2.0$ & $6.3 \pm 0.8$ & $8.6 \pm 0.8$ & $7.9 \pm 1.2$ & $7.6 \pm 0.7$ & $12.1 \pm 0.7$ \\
\hline $1-2$ & $55 \pm 24$ & $55 \pm 12$ & $114 \pm 35$ & $73 \pm 6$ & $58 \pm 5$ & $95 \pm 7$ & $0.7 \pm 0.3$ & $0.7 \pm 0.2$ & $1.7 \pm 0.6$ & $1.0 \pm 0.1$ & $0.7 \pm 0.1$ & $1.8 \pm 0.1$ \\
\hline $5-10$ & $96 \pm 14$ & $61 \pm 9$ & $131 \pm 49$ & $178 \pm 33$ & $120 \pm 19$ & $177 \pm 26$ & $0.9 \pm 0.1$ & $0.6 \pm 0.1$ & $2.0 \pm 0.8$ & $2.5 \pm 0.7$ & $1.3 \pm 0.2$ & $3.1 \pm 0.4$ \\
\hline $10-20$ & $91 \pm 43$ & $69 \pm 31$ & $249 \pm 125$ & $262 \pm 46$ & $111 \pm 41$ & $163 \pm 35$ & $0.7 \pm 0.3$ & $0.4 \pm 0.2$ & $3.5 \pm 2.1$ & $2.3 \pm 0.2$ & $1.2 \pm 0.4$ & $2.0 \pm 0.6$ \\
\hline $20-100$ & $687 \pm 341$ & $198 \pm 142$ & $423 \pm 356$ & $121 \pm 63$ & $7 \pm 7$ & $491 \pm 262$ & $5.7 \pm 3.1$ & $1.5 \pm 1.1$ & $5.3 \pm 4.4$ & $1.0 \pm 0.5$ & $0.1 \pm 0.1$ & $5.8 \pm 2.9$ \\
\hline Elements & \multicolumn{6}{|c|}{$\mathrm{P}$} & \multicolumn{6}{|c|}{$\mathrm{Ca}$} \\
\hline Site & $\mathrm{C} 1$ & $\mathrm{C} 2$ & $\mathrm{C} 4$ & C6 & $\mathrm{C} 8$ & $\mathrm{C} 9$ & $\mathrm{C} 1$ & $\mathrm{C} 2$ & $\mathrm{C} 4$ & C6 & $\mathrm{C} 8$ & C9 \\
\hline $0-1$ & $0.35 \pm 0.14$ & $0.28 \pm 0.04$ & $0.30 \pm 0.02$ & $0.42 \pm 0.04$ & $0.56 \pm 0.04$ & $0.55 \pm 0.10$ & $2.8 \pm 1.2$ & $2.1 \pm 0.6$ & $2.7 \pm 0.2$ & $2.8 \pm 0.2$ & $3.6 \pm 0.5$ & $3.4 \pm 0.1$ \\
\hline $1-2$ & $0.04 \pm 0.01$ & $0.06 \pm 0.01$ & $0.07 \pm 0.02$ & $0.06 \pm 0.01$ & $0.09 \pm 0.01$ & $0.07 \pm 0.01$ & $0.4 \pm 0.1$ & $0.4 \pm 0.1$ & $0.9 \pm 0.3$ & $0.5 \pm 0.01$ & $0.6 \pm 0.04$ & $0.9 \pm 0.1$ \\
\hline $2-5$ & $0.05 \pm 0.01$ & $0.07 \pm 0.01$ & $0.09 \pm 0.01$ & $0.10 \pm 0.02$ & $0.12 \pm 0.02$ & $0.13 \pm 0.01$ & $0.8 \pm 0.2$ & $1.3 \pm 0.1$ & $2.1 \pm 0.2$ & $1.4 \pm 0.3$ & $1.5 \pm 0.3$ & $2.5 \pm 0.3$ \\
\hline $5-10$ & $0.07 \pm 0.01$ & $0.06 \pm 0.01$ & $0.08 \pm 0.02$ & $0.20 \pm 0.05$ & $0.19 \pm 0.04$ & $0.10 \pm 0.01$ & $0.6 \pm 0.2$ & $0.4 \pm 0.03$ & $1.1 \pm 0.3$ & $1.4 \pm 0.4$ & $1.6 \pm 0.2$ & $1.7 \pm 0.2$ \\
\hline $10-20$ & $0.04 \pm 0.03$ & $0.02 \pm 0.01$ & $0.17 \pm 0.10$ & $0.13 \pm 0.04$ & $0.28 \pm 0.14$ & $0.05 \pm 0.03$ & $0.6 \pm 0.3$ & $0.6 \pm 0.3$ & $2.4 \pm 1.4$ & $2.2 \pm 0.1$ & $1.3 \pm 0.4$ & $1.6 \pm 0.4$ \\
\hline $20-100$ & $0.35 \pm 0.20$ & $0.14 \pm 0.13$ & $0.18 \pm 0.13$ & $0.06 \pm 0.03$ & $0.02 \pm 0.02$ & $0.05 \pm 0.02$ & $4.1 \pm 1.7$ & $1.4 \pm 0.9$ & $3.4 \pm 2.7$ & $0.8 \pm 0.4$ & $0.1 \pm 0.1$ & $4.6 \pm 2.4$ \\
\hline Elements & \multicolumn{6}{|c|}{$\mathrm{Mg}$} & \multicolumn{6}{|c|}{$\mathrm{K}$} \\
\hline Site & $\mathrm{C} 1$ & $\mathrm{C} 2$ & $\mathrm{C} 4$ & C6 & $\mathrm{C} 8$ & C9 & $\mathrm{C} 1$ & $\mathrm{C} 2$ & $\mathrm{C} 4$ & C6 & $\mathrm{C} 8$ & C9 \\
\hline $0-1$ & $0.54 \pm 0.20$ & $0.44 \pm 0.13$ & $0.50 \pm 0.02$ & $0.43 \pm 0.05$ & $0.82 \pm 0.12$ & $0.76 \pm 0.08$ & $2.0 \pm 0.8$ & $1.4 \pm 0.3$ & $2.1 \pm 0.2$ & $1.7 \pm 0.2$ & $2.7 \pm 0.7$ & $2.7 \pm 0.5$ \\
\hline $1-2$ & $0.06 \pm 0.02$ & $0.07 \pm 0.03$ & $0.12 \pm 0.03$ & $0.05 \pm 0.01$ & $0.10 \pm 0.01$ & $0.14 \pm 0.01$ & $0.3 \pm 0.1$ & $0.4 \pm 0.1$ & $0.6 \pm 0.1$ & $0.3 \pm 0.04$ & $0.5 \pm 0.1$ & $0.5 \pm 0.1$ \\
\hline $2-5$ & $0.09 \pm 0.02$ & $0.15 \pm 0.02$ & $0.18 \pm 0.02$ & $0.13 \pm 0.02$ & $0.16 \pm 0.04$ & $0.27 \pm 0.02$ & $0.4 \pm 0.1$ & $0.6 \pm 0.05$ & $0.8 \pm 0.1$ & $0.6 \pm 0.1$ & $0.7 \pm 0.2$ & $0.9 \pm 0.1$ \\
\hline $5-10$ & $0.10 \pm 0.04$ & $0.06 \pm 0.01$ & $0.14 \pm 0.04$ & $0.16 \pm 0.04$ & $0.21 \pm 0.03$ & $0.20 \pm 0.02$ & $0.4 \pm 0.04$ & $0.3 \pm 0.04$ & $0.5 \pm 0.1$ & $0.7 \pm 0.1$ & $0.8 \pm 0.2$ & $0.8 \pm 0.1$ \\
\hline $10-20$ & $0.09 \pm 0.05$ & $0.07 \pm 0.04$ & $0.28 \pm 0.15$ & $0.22 \pm 0.04$ & $0.20 \pm 0.08$ & $0.18 \pm 0.04$ & $0.4 \pm 0.2$ & $0.4 \pm 0.2$ & $1.0 \pm 0.4$ & $1.1 \pm 0.3$ & $0.6 \pm 0.2$ & $0.7 \pm 0.04$ \\
\hline $20-100$ & $0.69 \pm 0.33$ & $0.20 \pm 0.12$ & $0.37 \pm 0.30$ & $0.10 \pm 0.05$ & $0.01 \pm 0.01$ & $0.64 \pm 0.43$ & $3.9 \pm 1.9$ & $1.0 \pm 0.6$ & $1.6 \pm 1.2$ & $0.5 \pm 0.3$ & $0.04 \pm 0.04$ & $2.3 \pm 1.5$ \\
\hline
\end{tabular}


Table 3b. Root nutrient contents ( $\mathrm{g} \mathrm{m}^{-2}$ ) by soil depth (Mean $\pm \mathrm{SE}$ ).

\begin{tabular}{|c|c|c|c|c|c|c|c|c|c|c|c|c|}
\hline \multirow{2}{*}{$\begin{array}{c}\text { Elements } \\
\text { Site }\end{array}$} & \multicolumn{6}{|c|}{$\mathrm{C}$} & \multicolumn{6}{|c|}{$\mathrm{N}$} \\
\hline & $\mathrm{C} 1$ & $\mathrm{C} 2$ & $\mathrm{C} 4$ & C6 & $\mathrm{C} 8$ & C9 & $\mathrm{C} 1$ & $\mathrm{C} 2$ & $\mathrm{C} 4$ & C6 & $\mathrm{C} 8$ & C9 \\
\hline Oie & $560 \pm 323$ & $2 \pm 1$ & $83 \pm 69$ & $73 \pm 21$ & $14 \pm 1$ & $233 \pm 208$ & $4.7 \pm 2.8$ & $0.4 \pm 0.1$ & $1.7 \pm 1.2$ & $1.8 \pm 0.1$ & $0.3 \pm 0.03$ & $3.7 \pm 2.9$ \\
\hline $\mathrm{Oa}$ & $98 \pm 44$ & $225 \pm 93$ & $292 \pm 77$ & $308 \pm 139$ & $151 \pm 54$ & $339 \pm 175$ & $1.1 \pm 0.3$ & $2.9 \pm 1.0$ & $4.7 \pm 0.6$ & $4.3 \pm 2.1$ & $2.7 \pm 0.9$ & $6.7 \pm 3.1$ \\
\hline $0-10$ & $355 \pm 68$ & $306 \pm 64$ & $537 \pm 209$ & $340 \pm 30$ & $255 \pm 41$ & $349 \pm 84$ & $4.1 \pm 0.7$ & $3.6 \pm 0.1$ & $7.8 \pm 2.5$ & $4.6 \pm 0.2$ & $3.8 \pm 0.5$ & $5.9 \pm 1.1$ \\
\hline $10-30$ & $160 \pm 54$ & $131 \pm 20$ & $341 \pm 74$ & $202 \pm 21$ & $259 \pm 13$ & $455 \pm 57$ & $2.2 \pm 0.7$ & $1.8 \pm 0.1$ & $5.3 \pm 1.1$ & $2.9 \pm 0.6$ & $3.7 \pm 0.3$ & $7.9 \pm 0.9$ \\
\hline $30-50$ & $187 \pm 150$ & $82 \pm 22$ & $109 \pm 18$ & $67 \pm 11$ & $90 \pm 19$ & $146 \pm 36$ & $2.1 \pm 1.7$ & $1.2 \pm 0.4$ & $1.5 \pm 0.2$ & $1.1 \pm 0.2$ & $1.1 \pm 0.2$ & $2.5 \pm 0.6$ \\
\hline $50-\mathrm{C}$ & $41 \pm 15$ & $22 \pm 17$ & $95 \pm 47$ & $14 \pm 14$ & $26 \pm 17$ & $69 \pm 25$ & $0.5 \pm 0.2$ & $0.3 \pm 0.3$ & $1.4 \pm 0.7$ & $0.3 \pm 0.3$ & $0.3 \pm 0.2$ & $1.2 \pm 0.4$ \\
\hline $\mathrm{C}$ & $21 \pm 7$ & $32 \pm 17$ & $66 \pm 27$ & $123 \pm 29$ & $10 \pm 4$ & $15 \pm 6$ & $0.3 \pm 0.1$ & $0.4 \pm 0.2$ & $1.0 \pm 0.4$ & $2.0 \pm 0.5$ & $0.1 \pm 0.1$ & $0.3 \pm 0.1$ \\
\hline \multicolumn{3}{|l|}{ Elements } & \multicolumn{2}{|c|}{$\mathrm{P}$} & \multicolumn{2}{|l|}{ 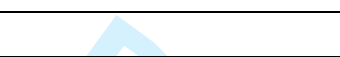 } & \multicolumn{6}{|c|}{$\mathrm{Ca}$} \\
\hline Site & $\mathrm{C} 1$ & $\mathrm{C} 2$ & $\mathrm{C} 4$ & C6 & $\mathrm{C} 8$ & C9 & $\mathrm{C} 1$ & $\mathrm{C} 2$ & $\mathrm{C} 4$ & C6 & $\mathrm{C} 8$ & C9 \\
\hline Oie & $0.31 \pm 0.23$ & $0.36 \pm 0.19$ & $0.09 \pm 0.06$ & $0.12 \pm 0.03$ & $0.02 \pm 0.002$ & $0.14 \pm 0.09$ & $3.3 \pm 1.8$ & $0.4 \pm 0.2$ & $0.9 \pm 0.7$ & $0.8 \pm 0.3$ & $0.3 \pm 0.0$ & $2.7 \pm 2.4$ \\
\hline $\mathrm{Oa}$ & $0.06 \pm 0.01$ & $0.22 \pm 0.12$ & $0.17 \pm 0.01$ & $0.28 \pm 0.11$ & $0.29 \pm 0.11$ & $0.17 \pm 0.05$ & $0.8 \pm 0.2$ & $2.1 \pm 0.7$ & $3.2 \pm 0.8$ & $2.2 \pm 0.9$ & $1.8 \pm 0.7$ & $3.4 \pm 1.9$ \\
\hline $0-10$ & $0.23 \pm 0.06$ & $0.12 \pm 0.005$ & $0.25 \pm 0.12$ & $0.23 \pm 0.05$ & $0.30 \pm 0.05$ & $0.18 \pm 0.02$ & $3.1 \pm 0.9$ & $2.1 \pm 0.3$ & $3.9 \pm 1.1$ & $3.3 \pm 0.3$ & $2.5 \pm 0.4$ & $2.9 \pm 0.8$ \\
\hline $10-30$ & $0.12 \pm 0.04$ & $0.11 \pm 0.01$ & $0.19 \pm 0.04$ & $0.16 \pm 0.02$ & $0.46 \pm 0.10$ & $0.24 \pm 0.06$ & $1.1 \pm 0.5$ & $0.7 \pm 0.1$ & $2.7 \pm 0.7$ & $1.4 \pm 0.3$ & $3.1 \pm 0.1$ & $4.0 \pm 0.2$ \\
\hline $30-50$ & $0.13 \pm 0.10$ & $0.08 \pm 0.02$ & $0.08 \pm 0.01$ & $0.07 \pm 0.01$ & $0.14 \pm 0.03$ & $0.12 \pm 0.04$ & $0.9 \pm 0.7$ & $0.6 \pm 0.3$ & $0.8 \pm 0.1$ & $0.5 \pm 0.05$ & $0.8 \pm 0.1$ & $1.1 \pm 0.3$ \\
\hline $50-\mathrm{C}$ & $0.03 \pm 0.01$ & $0.02 \pm 0.02$ & $0.06 \pm 0.03$ & $0.01 \pm 0.01$ & $0.03 \pm 0.02$ & $0.06 \pm 0.02$ & $0.2 \pm 0.1$ & $0.2 \pm 0.1$ & $0.7 \pm 0.3$ & $0.1 \pm 0.1$ & $0.2 \pm 0.1$ & $0.6 \pm 0.2$ \\
\hline $\mathrm{C}$ & $0.02 \pm 0.01$ & $0.03 \pm 0.01$ & $0.05 \pm 0.02$ & $0.11 \pm 0.01$ & $0.01 \pm 0.01$ & $0.02 \pm 0.01$ & $0.1 \pm 0.03$ & $0.2 \pm 0.1$ & $0.4 \pm 0.2$ & $0.8 \pm 0.2$ & $0.1 \pm 0.05$ & $0.1 \pm 0.04$ \\
\hline \multicolumn{3}{|l|}{ Elements } & \multicolumn{2}{|c|}{$\mathrm{Mg}$} & & & \multicolumn{6}{|c|}{$\mathrm{K}$} \\
\hline Site & $\mathrm{C} 1$ & $\mathrm{C} 2$ & $\mathrm{C} 4$ & C6 & $\mathrm{C} 8$ & C9 & $\mathrm{C} 1$ & $\mathrm{C} 2$ & $\mathrm{C} 4$ & C6 & $\mathrm{C} 8$ & C9 \\
\hline Oie & $0.57 \pm 0.32$ & $0.36 \pm 0.19$ & $0.13 \pm 0.11$ & $0.10 \pm 0.03$ & $0.02 \pm 0.002$ & $0.49 \pm 0.43$ & $3.3 \pm 1.8$ & $0.4 \pm 0.2$ & $0.3 \pm 0.2$ & $0.2 \pm 0.1$ & $0.1 \pm 0.01$ & $1.6 \pm 1.5$ \\
\hline $\mathrm{Oa}$ & $0.12 \pm 0.04$ & $0.30 \pm 0.12$ & $0.40 \pm 0.12$ & $0.30 \pm 0.13$ & $0.29 \pm 0.11$ & $0.33 \pm 0.13$ & $0.6 \pm 0.2$ & $1.3 \pm 0.5$ & $1.7 \pm 0.4$ & $1.3 \pm 0.6$ & $0.8 \pm 0.2$ & $1.5 \pm 0.6$ \\
\hline $0-10$ & $0.39 \pm 0.07$ & $0.28 \pm 0.0$ & $0.40 \pm 0.11$ & $0.30 \pm 0.05$ & $0.45 \pm 0.06$ & $0.37 \pm 0.02$ & $1.8 \pm 0.4$ & $1.2 \pm 0.2$ & $1.8 \pm 0.2$ & $1.3 \pm 0.4$ & $1.8 \pm 0.4$ & $1.3 \pm 0.1$ \\
\hline $10-30$ & $0.20 \pm 0.07$ & $0.15 \pm 0.03$ & $0.36 \pm 0.10$ & $0.20 \pm 0.01$ & $0.50 \pm 0.01$ & $0.63 \pm 0.08$ & $0.8 \pm 0.3$ & $0.6 \pm 0.1$ & $1.6 \pm 9.2$ & $0.9 \pm 0.03$ & $1.8 \pm 0.1$ & $2.2 \pm 0.5$ \\
\hline $30-50$ & $0.21 \pm 0.17$ & $0.14 \pm 0.08$ & $0.13 \pm 0.03$ & $0.06 \pm 0.01$ & $0.18 \pm 0.03$ & $0.22 \pm 0.07$ & $0.7 \pm 0.6$ & $0.4 \pm 0.2$ & $0.6 \pm 0.04$ & $0.4 \pm 0.1$ & $0.7 \pm 0.2$ & $0.8 \pm 0.3$ \\
\hline $50-\mathrm{C}$ & $0.05 \pm 0.02$ & $0.02 \pm 0.01$ & $0.11 \pm 0.05$ & $0.01 \pm 0.01$ & $0.05 \pm 0.03$ & $0.11 \pm 0.05$ & $0.2 \pm 0.1$ & $0.1 \pm 0.1$ & $0.4 \pm 0.2$ & $0.1 \pm 0.1$ & $0.2 \pm 0.2$ & $0.4 \pm 0.2$ \\
\hline $\mathrm{C}$ & $0.02 \pm 0.01$ & $0.04 \pm 0.03$ & $0.07 \pm 0.03$ & $0.11 \pm 0.02$ & $0.02 \pm 0.01$ & $0.02 \pm 0.01$ & $0.1 \pm 0.04$ & $0.2 \pm 0.1$ & $0.3 \pm 0.1$ & $0.6 \pm 0.1$ & $0.1 \pm 0.04$ & $0.1 \pm 0.1$ \\
\hline
\end{tabular}




\section{Figure captions}

503 Figure 1 . Concentrations of $\mathrm{C}, \mathrm{N}, \mathrm{P}, \mathrm{Ca}, \mathrm{Mg}$, and $\mathrm{K}$ in roots by diameter class and soil 504 depth in six sites at Bartlett Experimental Forest. Error bars represent the standard error 505 of three soil pits. Samples without bars represent means of three pits composited before 506 chemical analysis.

508 Figure 2. Nutrient content of C, N, P, Ca, Mg, and $\mathrm{K}$ of roots up to $20 \mathrm{~mm}$ in diameter 509 for six sites at Bartlett Experimental Forest based on concentration data from all the 510 roots that were analyzed ("All”) or on a subset of the data, either the roots in the Oa 511 horizon only ("Oa") or the roots from the top $10 \mathrm{~cm}$ of the mineral soil ("0-10 cm"). 512 Error bars represent the standard error of three soil pits. 
Figure 1.

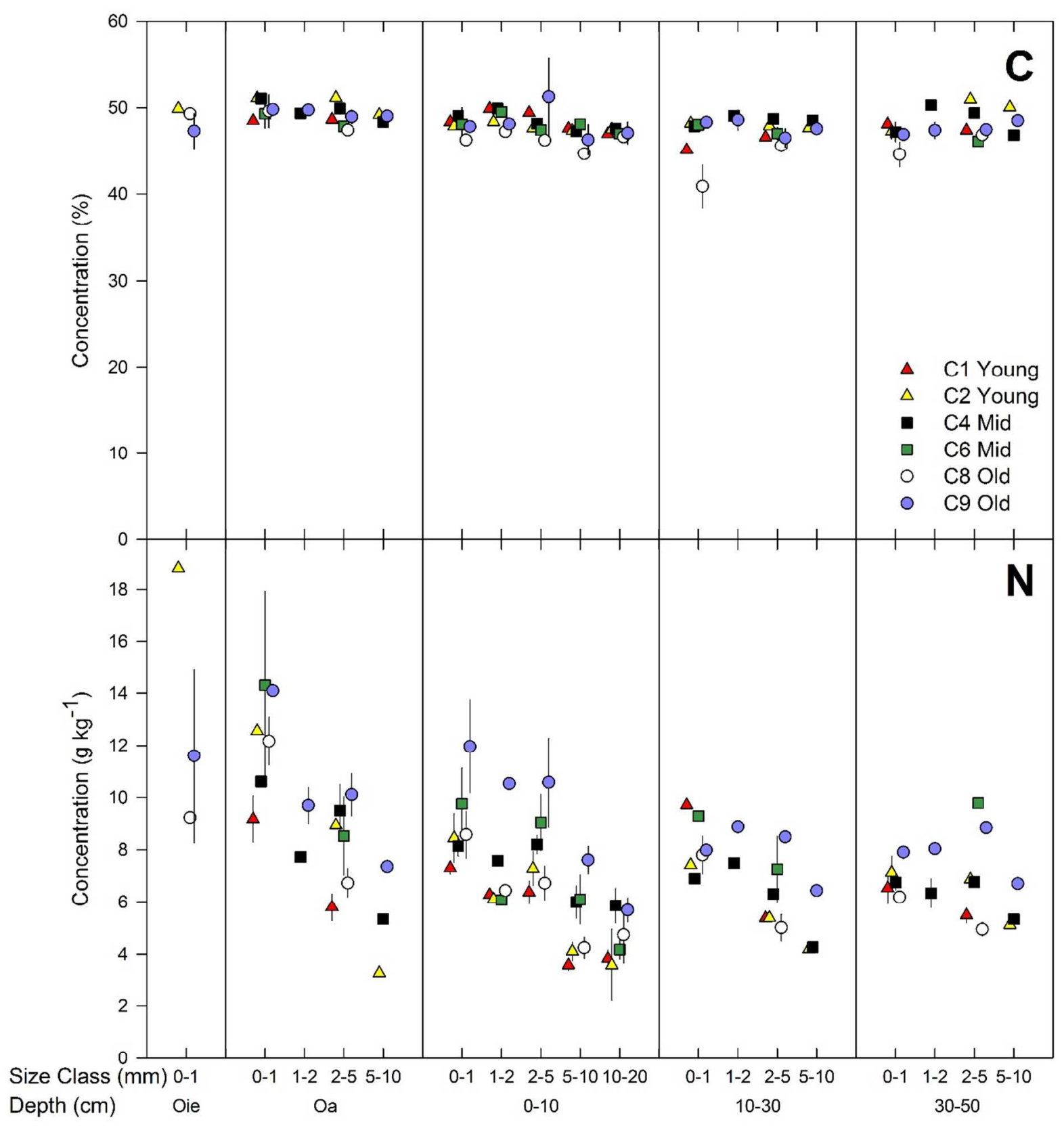


Figure 1, cont.

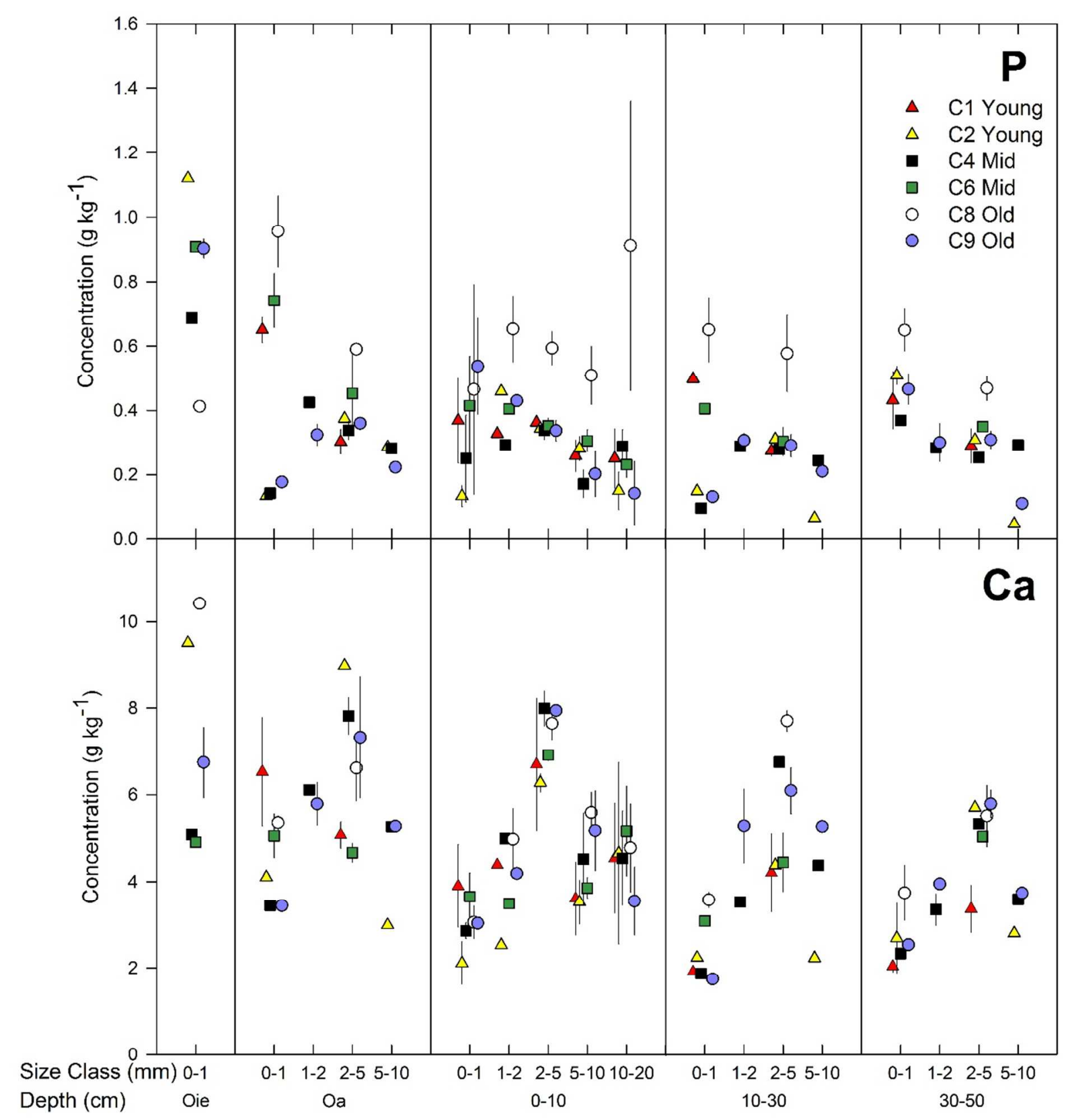


Figure 1, cont.

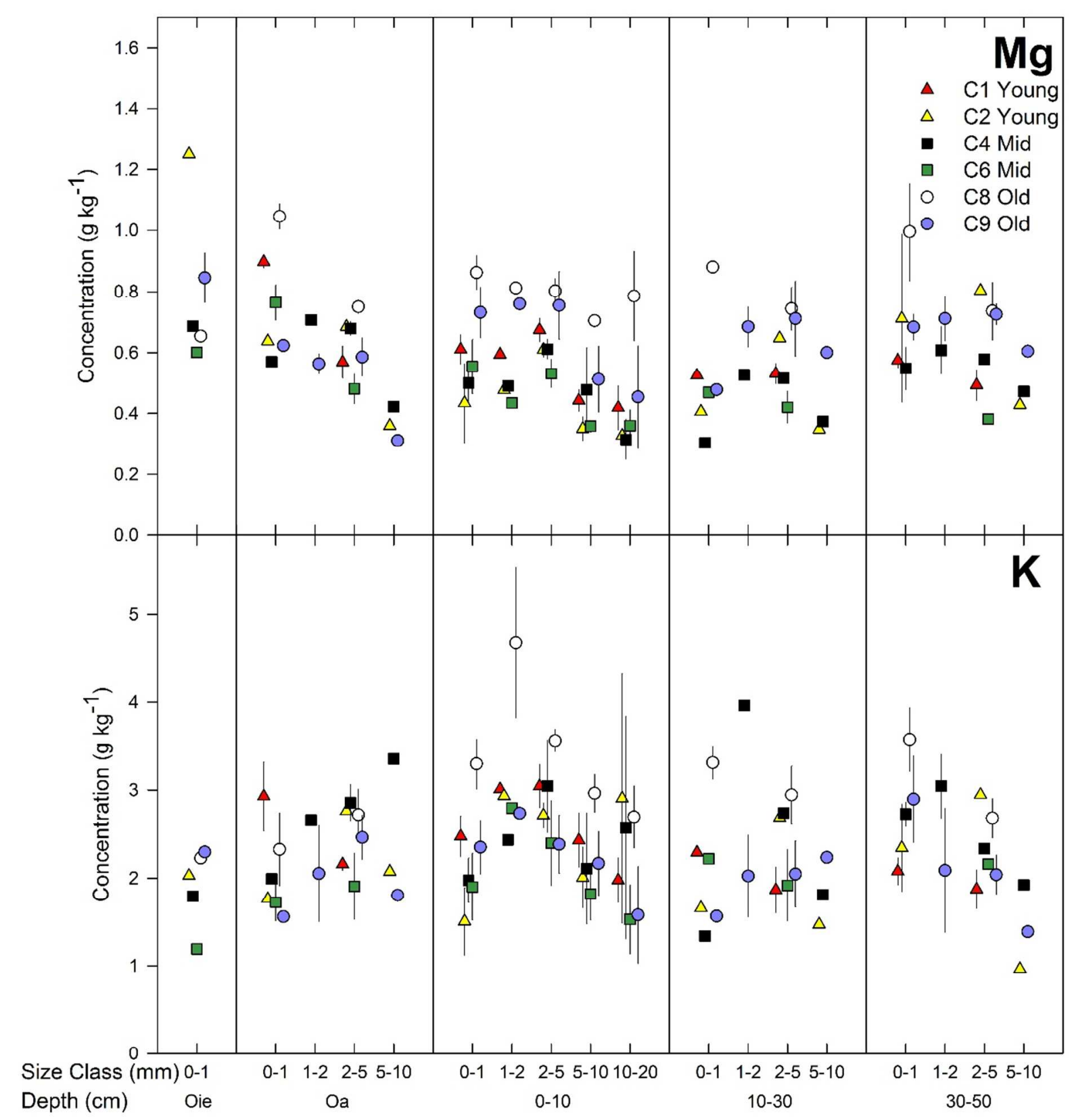


Fig. 2.
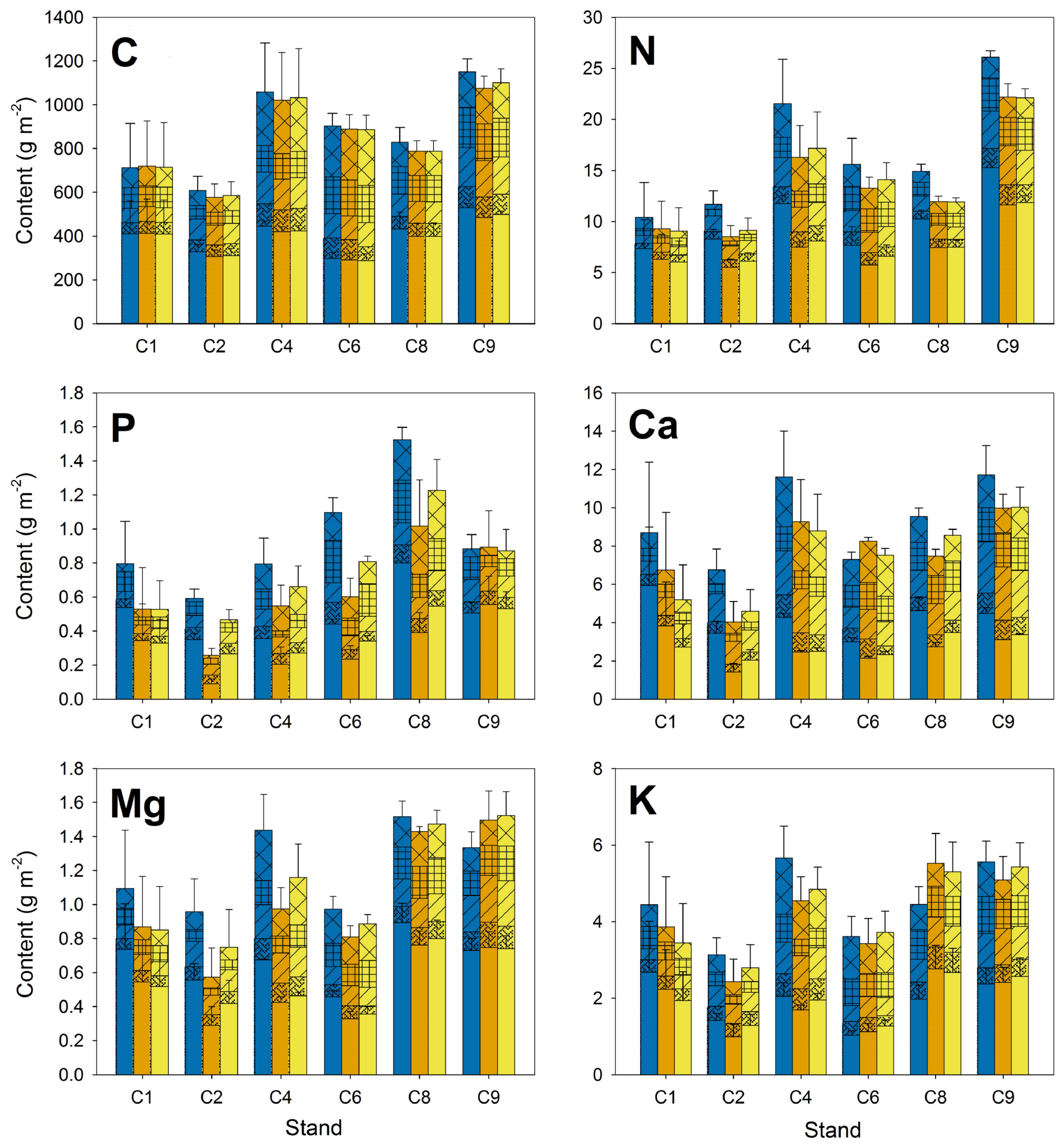

\begin{tabular}{|ll|}
\hline$\square 10-20 \mathrm{~mm}$ & Oa \\
$5-10 \mathrm{~mm}$ & 0-10 cm \\
$\square \backslash \lambda 2-5 \mathrm{~mm}$ & All \\
$1-2 \mathrm{~mm}$ & \\
$\square$ 0-1 mm & \\
\hline
\end{tabular}

